\title{
Justyna Konikowska-Kuczyńska
}

University of Bialystok, Poland

ORCID: 0000-0001-9919-9248

j.konikowskakuczynska@uwb.edu.pl

\section{Admissibility of Unconventional Trade Marks Registration within the European Court of Justice Statements}

\author{
Dopuszczalność rejestracji niekonwencjonalnych znaków \\ towarowych w orzecznictwie Trybunału Sprawiedliwości UE
}

\section{SUMMARY}

On 16 March 2019 the amendment of the Act - the Industrial Property Law, which implemented the European Parliament and EU Council Directive 2015/2436 of 16 December 2015, aiming the rapprochement of legislation within the membership countries regarding trade marks. The essential change, that the amendment implemented is the cancellation of the necessity of graphical representation of the trade mark, what allows to simplify the registration of the unconventional trade marks. The purpose of the article is to present how the registration of unconventional trade marks looked within the light of the Luxembourg tribunal's statements. istration

Keywords: trade mark; unconventional trade marks; graphical representation; trade marks reg-

\section{INTRODUCTION}

On 16 March 2019 the amendment of the Act - the Industrial Property Law came into an effect ${ }^{1}$. With the Act there has been implemented the European Parliament and EU Council Directive 2015/2436 of 16 December 2015, aiming the rapprochement of legislation within the membership countries regarding trade

1 Act of 20 February 2019 amending the Industrial Property Law (Journal of Laws 2019, item 501), hereinafter: IPL. 
marks ${ }^{2}$. The amendment implemented some essential changes: a new definition of the trade mark, among others cancellation of the necessity of graphical representation, which has been present within the previous version. The EU legislator and following him the national legislator made easier to register the unconventional trade marks. It has been admitted, that there occurs the necessity of modernization of the trade mark system in the European Union as a whole as well as adopting it to the Internet era, so the registration systems of the trade marks could be faster, simpler and of better quality, as well as more consistent, user friendly with public access and they could work with modern technologies ${ }^{3}$.

The rule of Article $3^{4}$ of the Directive 2015/2436 had been implemented on 1 October 2017. The change of the definition of the trade mark refers to the new qualification of trade mark representation. This standard, as M. Ziółkowski ${ }^{5}$ writes, has not been cancelled in total, but was replaced with more detailed guidelines, arising of the Court of Justice judgement of 12 December 2002 for the Sieckmann case $^{6}$. Due to Article 3 of the Directive 2015/2436 the subject that wants to get the trade mark protected, is not absolutely committed to represent the mark in the graphic form. Up to implementation of the new definition for mark referring to the unconventional trade marks fulfilling the indications stated within the Sieckmann case has been troubled with lack of the proper technical resources. The problem, as E. Wojcieszko-Głuszko writes, was widely noticed. That was the reason to postulate the need to tone down the registration practice of unconventional trade marks, as well as to reformulate the graphical representation premise, simultaneously not lowering the significance of the Sieckmann's seven criteria ${ }^{7}$. It comes out of Article 3 of the Directive 2015/2436, that a trade mark can be a sign, which can be represented within the register in the manner which enables to determine the clear

2 Directive (EU) 2015/2436 of the European Parliament and of the Council of 16 December 2015 to approximate the laws of the Member States relating to trade marks (recast) (OJ EU L 336/1, 23.12.2015), hereinafter: Directive 2015/2436.

3 Directive 2015/2436, point 6 of the preamble.

4 A trade mark may consist of any signs, in particular words, including personal names, or designs, letters, numerals, colours, the shape of goods or of the packaging of goods, or sounds, provided that such signs are capable of: distinguishing the goods or services of one undertaking from those of other undertakings and being represented on the register in a manner which enables the competent authorities and the public to determine the clear and precise subject matter of the protection afforded to its proprietor.

5 M. Ziółkowski, Zmiany w zakresie wymogu przedstawialności znaku towarowego w dyrektywie 2015/2436/12, „Przegląd Prawa Handlowego” 2016, no. 12, pp. 13-144.

6 Judgement of the CJEU of 12 December 2002, case C-273/00, Ralf Sieckmann v. Deutsches Patent- und Markenamt, ECLI:EU:C:2002:748, hereinafter: judgement for the Sieckmann case.

7 E. Wojcieszko-Głuszko, Pojęcie znaku towarowego. Rodzaje oznaczeń. Kategorie znaków towarowych, [in:] System Prawa Prywatnego, vol. 14b: Prawo własności przemysłowej, ed. R. Skubisz, Legalis/el. 2017, p. 9. 
and precise subject matter of the protection afforded to its proprietor. In the light of point 13 of the preamble to the Directive 2015/2436 admissible is every form of mark representation, which uses commonly accessible technology, what means not particularly graphics, but the way of representation must be clear, precise, self-contained, easily accessible, intelligible, durable and objective ${ }^{8}$. As result there has been founded a system, protecting the marks in the form they were submitted ("what you see is what you get"), what made the readability, accessibility and ease of searching the enrollments in the trade marks register of the $\mathrm{EU}^{9}$. Implementation of the Directive regulations to the Polish law order was strongly connected with the necessity of changing the trade mark definition stated within Article 120 IPL $^{10}$. The most important change implemented with the amendment was the cancellation of the necessity of graphical representation ${ }^{11}$.

\section{KINDS OF REPRESENTATION FORMS OF TRADE MARKS}

Of the rule within Article 120 IPL of new reading it comes out that a trade mark can be any sign, making it possible to distinguish the products of a company from the products of other companies and enabling to represent within the register in the manner which enables to determine the clear and precise subject matter of the protection afforded to its proprietor. In Article 120 (2) IPL the legislator included the open catalogue of the permissible representation forms of trade marks: word, including name, drawing, number, colour, spatial form including the form of goods or their packaging, as well as sound. One has to point, that the fundamental attribute of the trade mark is its distinctive ability, which can be stated as abstractive, that means independent of the product with potential ability to distinguish similar kind

8 Directive 2015/2436, Article 3 point 13 of the preamble.

9 Przedstawienie graficzne - rodzaje znaków, https:/euipo.europa.eu/ohimportal/pl/elimination-of-graphical-representation-requirement [access: 5.12.2019].

10 Article 120 (1) of the Act of 20 June 2000 - Industrial Property Law (Journal of Laws 2017, item 776).

11 As per hitherto Article 120 IPL a trade mark was any graphically representable sign or such, which could be explained in a graphic way, if such a sign could be used to distinguish the products of a company within the trade from same kind of products of other companies. To perform as a trade mark the sign had to possess two attributes jointly: to be possible of graphic representation and to be suitable to distinguish products of a company from products of other companies, that is possession of abstractive distinguish ability lack of ability to conform any of the prerequisites resulted with issuing the refusal decision for righ of protection for the trade mark by the Patent Office of the Republic of Poland. See M. Rutkowska-Sowa, Prawo znaków towarowych, [in:] Prawo własności intelektualnej, ed. J. Sieńczyło-Chlabicz, Warszawa 2018, p. 453. 
of products in trade, what determines adjudgement as trade mark ${ }^{12}$. The Patent Office of the Republic of Poland distinguishes the following trade mark categories: word, graphics, word-graphic, spatial, positional, sound characters, colour, pattern, movable, multimedia, holograms and others ${ }^{13}$. European Union Intellectual Property Office disthinguishes the trade marks as follows: word, figurative, shape, position, pattern, colour (single), colour (combination), sound, motion, multimedia and hologram ${ }^{14}$. Of the rules regarding trade marks included within Article 4 of the Regulation 2017/1001 of the European Parliament and of the Council of 14 June 2017 on the European Union trade mark ${ }^{15}$ it comes out, that a trade mark may consist of any of the following signs, in particular words, including family names, or designs, letters, numbers, colours, shape of the goods or their packaging, and sound; under the condition that those marks make it able to distinguish products and services of one company from the products and services of the other. The marks have to become represented within the register in the way that permits the proper organs and receivers to state the clear and precise subject matter of the protection afforded to the proprietor of the trade mark.

Referring to the problem range covered by the article, the doctrine representatives provided the division of the trade marks to conventional and unconventional. In total to the conventional marks one may count the words, graphics and word-graphic, and to the unconventional ones: spatial, positional, audible, colour, pattern, movable, multimedia, hologram and others. Within the doctrine, one may distinguish different representational forms of signs basing on the way of their perception. According to J. Koczanowski, there exist the following trade marks: words, graphics, plastic and combined ${ }^{16}$. The doctrine states also the word marks that may be received with sight and hearing, the graphic and "colour" marks received with sight, sight and touch plastic marks, as well as audible marks received with hearing. The trade mark classification made by the criteria of perception is stated traditional by the doctrine and widely accepted ${ }^{17}$. Due to the perception standard, the signs could be divided as conventional, perceived with sight and unconventional, perceived with sight (visible signs) or other senses (invisible signs) ${ }^{18}$. The conventional sign forms are at first the words, perceived with sight or hearing,

12 Judgement of the Supreme Administrative Court of 9 December 2011, GSK 1346/10, LEX no. 1134648.

${ }^{13}$ Co to jest znak towarowy?, https://uprp.gov.pl/p1/przedmioty-ochrony/znaki-towarowe/znaki-towarowe-informacje-podstawowe/co-to-jest-znak-towarowy [access: 5.04.2020].

${ }_{14}$ Definicja znaku towarowego, https://euipo.europa.eu/ohimportal/pl/trade-mark-definition [access: 5.04.2020].

15 OJ EU L 154/1, 16.06.2017, hereinafter: the Regulation 2017/1001.

16 J. Koczanowski, Funkcje i ochrona prawna znaków towarowych, „Zeszyty Naukowe Uniwersytetu Jagiellońskiego. Prace z Wynalazczości i Ochrony Własności Intelektualnej” 1976, no. 8, p. 25.

${ }_{17}$ For more, see E. Wojcieszko-Głuszko, op. cit., pp. 14-15.

${ }^{18}$ M. Ziółkowski, Rodzaje znaków towarowych ze względu na ich percepcję zmystami oraz przedstawialność w rejestrze, „Przegląd Prawa Handlowego” 2015, no. 1, p. 54 ff. 
consisting of numbers, letters or their composition (there can be registered single words, names, phrases, neologisms and catchwords) $)^{19}$, as well as graphic marks (pictures) - perceived only with sight, e.g. graphics, ornaments, monograms ${ }^{20}$. The unconventional marks cover the two groups: the signs perceived with sight and those perceived with senses other than sight ${ }^{21}$. The doctrine states that the unconventional visible signs are colours per se (that means spatially unlimited), plastic marks, positional marks, holograms and moving marks (including animated) and gestures. The plastic and three-dimensional (3D) marks are stated as spatial. The unconventional invisible signs in their way are: sound marks, toucheables, scent and taste ${ }^{22}$. In my opinion, such partition should be treated as proper. Of the communicate of Ministry of Development it comes out, that the following types of marks have been accepted: taste, scent and hologram. Due to this, "the entrepreneurs would be able to include a wider palette for the creation of their trade marks. [...] The entrepreneur would be able to protect a 3D figure within the Patent Office"23.

\section{NORMATIVE PREREQUISITES FOR UNCONVENTIONAL TRADE MARK REGISTRATION}

The national procedure regarding the trade mark registration, it is initiated by filing a trade mark application before the Polish Patent Office, which is then tested for law and formal conformity. The registration has a facultative character and provides decision about the right of protection of the mark. It also provides warranty against breaching stated within Article 296 IPL $^{24}$. The formal requirements for filing a trade mark application can be found in the Regulation of the Prime Minister of 8 December 2016 regarding filling and processing trade mark application ${ }^{25}$. The notification for a mark is made in the form of an application, which should include, among others, specification of the trade mark and indication of the goods for which the trade mark is intended, regulations of the trade mark (for filing a collective trade

19 J. Sitko, Znaki towarowe i prawa ochronne, [in:] Prawo własności przemysłowej. Komentarz, eds. T. Demendecki, A. Niewęgłowski, J. Sitko, J. Szczotka, G. Tylec, Warszawa 2015, p. 605.

${ }^{20}$ M. Andrzejewski, Znaki towarowe i oznaczenia geograficzne, [in:] Prawo własności przemystowej. Komentarz, ed. P. Kostański, Warszawa 2014, p. 795.

${ }^{21}$ E. Wojcieszko-Głuszko, op. cit., p. 15.

${ }^{22}$ Ibidem; U. Promińska, Znaki towarowe i prawo ochronne, [in:] Własność przemystowa i jej ochrona, eds. E. Nowińska, U. Promińska, K. Szczepanowska-Kozłowska, Warszawa 2014, p. 404.

${ }_{23}$ Prezydent podpisat nowelizację Prawa własności przemysłowej, 2019, www.gov.pl/web/ rozwoj/prezydent-podpisal-nowelizacje-prawa-wlasnosci-przemyslowej [access: 5.04.2020].

${ }^{24}$ M. Rutkowska-Sowa, op. cit., p. 473.

${ }_{25}$ Journal of Laws 2016, item 2053, hereinafter: the Regulation regarding trade marks. 
mark or filing a trade mark in order to obtain collective right of protection), details of the attorney if the applicant acts through $\mathrm{him}^{26}$.

Before granting the right of protection for a trade mark, the Patent Office only examines the absolute obstacles to obtaining the right of protection, as defined in Article $121^{1}$ IPL. Relative prerequisites specified in Article $131^{1}$ IPL may give rise to an objection ${ }^{27}$. The Polish Patent Office immediately publishes an announcement in the "Bulletin of the Patent Office" ("Biuletyn Urzędu Patentowego") about the application for a trade mark which has not been found to lack the conditions required to obtain the right of protection for the trade mark for the reasons referred to in Articles $129^{1}, 136^{1}, 136^{3}$ IPL. The Patent Office may issue a refusal to grant right of protection for a trade mark if it receives information about the circumstances of Articles 129', $136^{1}, 136^{3}$ IPL, and after the announcement of the trade mark application. Within 3 months from the date of announcement of the trade mark application, the holder of the earlier trade mark as well as the person with previous personal or property rights may object to the trade mark application for the reasons referred to in Article $129^{1}$ (4) or Article $132^{1}(1-3)$. It is important that this deadline cannot be restored ${ }^{28}$.

However, application of the union trade mark can be performed only in European Union Intellectual Property Office - EUIPO (Article 30 of the Regulation 2017/1001 ${ }^{29}$. An application for an EU trade mark shall include: a request for the registration of an EU trade mark, information identifying the applicant, a list of the goods or services in respect of which the registration is requested, a representation of the mark. The application for an EU trade mark shall be subject to the application fee, covering one class of goods or services ${ }^{30}$. One has to remember that registration of a trade mark has the same legal effects within the European Union. By registering a mark, it is entered in one trade mark register that is effective within the whole European Union ${ }^{31}$.

It is essential, that the trade mark registration system within the European Union is of objection type ${ }^{32}$. After the trade mark is reported, only the absolute prerequisites testing is performed. There is no testing of comparative prerequisites. The absolute prerequisite are testes on demand ${ }^{33}$. There is no call in question for the signs that are similar or identical to the previously registered signs. Within

26 Article 138 points 1 and 3 IPL and $\S 4$ of the Regulation regarding trade marks.

27 M. Rutkowska-Sowa, op. cit., p. 478.

28 Article $146^{1}$ (1) and (5) IPL, Article $152^{17}$ (1) IPL.

${ }^{29}$ M. Rutkowska-Sowa, op. cit., p. 498.

${ }^{30}$ Article 31 (1) and (2) of the Regulation 2017/1001.

${ }^{31}$ M. Rutkowska-Sowa, op. cit., p. 497.

32 Ibidem.

33 A. Szewc, M. Mazurek, Postepowanie w sprawie udzielenia prawa ochronnego na znak towarowy, [in:] System Prawa Prywatnego, vol. 14b: Prawo wtasności przemysłowej, ed. R. Skubisz, Warszawa 2012, p. 585. 
this kind of system the authorized to the previously registered marks, to prevent registration of similar or identical signs, have to submit the objection by themselves to the office on the submitting procedure ex officio as the testing is not performer ex officio ${ }^{34}$.

Within Article 3 of the EU Commission Implementing Regulation 2018/626 of 5 March $2018^{35}$ the EU legislator regulated the manner of presenting trade marks in the register. According to this provision, the trade mark shall be represented in any appropriate form using generally available technology, as long as it can be reproduced on the register in a clear, precise, self-contained, easily accessible, intelligible, durable and objective manner so as to enable the competent authorities and the public to determine with clarity and precision the subject matter of the protection afforded to its proprietor. Considering unconventional trade marks - consisting of or extending to a three-dimensional shape, they are presented by submitting a graphic reproduction of the shape, including computer-generated imaging or photographic reproduction. As regards the position mark, consisting of a specific method of applying or placing the mark on the goods, it is presented by submitting a reproduction specifying the position of the mark and its size or proportion with respect to the relevant goods. If the trade mark is a pattern and consists only of regularly repeating elements, it should be presented by submitting a reproduction showing the repetition pattern. In the case of a mark which is a colour and consists of only one colour without contours, the mark shall be represented by submitting a reproduction of the colour by indicating that colour by reference to a generally recognized colour code. However, if the mark is composed of a combination of colours without contours, it should be presented by submitting a reproduction showing the systematic arrangement of the combination of colours in a homogeneous and predetermined way, indicating these colours by reference to a generally recognized colour code. For a sound mark consisting solely of a sound or combination of sounds, an audio file reproducing the given sound should be submitted or by accurately representing the sound in the form of musical notation. A motion mark that consists of or extends to a movement or repositioning of the mark's elements is represented by assembling a video file or through a series of sequential still images illustrating movement or repositioning. A multimedia mark, i.e. an image and sound combination, or extends to such a combination, is presented by submitting an audiovisual file containing the image and sound combination.

${ }^{34}$ E. Demby-Siwek, Zmiana systemu rozpatrywania zgłoszeń znaków towarowych, „Kwartalnik Urzędu Patentowego RP” 2015, no. 4, p. 5.

${ }_{35}$ Commission Implementing Regulation (EU) 2018/626 of 5 March 2018 laying down detailed rules for implementing certain provisions of Regulation (EU) 2017/1001 of the European Parliament and of the Council on the European Union trade mark, and repealing Implementing Regulation (EU) 2017/1431 (OJ EU L 104/37, 24.04.2018), hereinafter: the Regulation 2018/626. 
A holographic mark consisting of holographic elements is presented by submitting a video file or graphic or photographic reproduction, including views necessary to sufficiently identify the holographic effect in whole.

\section{REVIEW OF JUDICIAL STATEMENTS}

The cause of registration of trade marks "escaping" the graphical representability criteria had become the matter for the Court of Justice multiple sessions. Analysis of case law, as well as the views of the representatives of the doctrine, allows the identification of characteristic elements related to this issue. Although the first judgements regarding unconventional marks were made at the background of the previously binding normative status, however the premises derived by the Luxembourg tribunal became the basis for the adoption of new solutions and the abandonment of the criterion of graphic representation of the mark. Within the range, the statement of the Sieckmann case referred to the olfactory mark rejected by the German patent office (the decision was submitted to the national court which by its way submitted the prejudicial question to the CJEU $)^{36}$. There were listed the seven attributes that the sign has to possess to fulfill the indicated prerequisite ${ }^{37}$. Within the statement, the CJEU pointed out that graphic representation of the mark in the register must be self-contained, easily accessible and intelligible ${ }^{38}$. The CJEU supported the position with the statement of 27 October 2005 in the case Eden SARL v. OHIM, "Smell of ripe strawberries" 39 , stating that "a trade mark may consist of a sign which is not in itself capable of being perceived visually, provided that it can be represented graphically, particularly by means of images, lines or characters, and that the representation is clear, precise, self-contained, easily accessible, intelligible, durable and objective. A graphic representation of a sign must enable the sign to be precisely identified in order to ensure the sound operation of the trade mark registration system". This position of the European Court of Justice has been taken into consideration within the novelty of the union law in Article 3 of the Regulation 2018/626 in which there had been clarified the requirements and principles, regarding the representation of most popular trade marks, as well as technical requirements depending on trade mark specifics.

${ }^{36}$ J. Mordwiłko-Osajda, Znak towarowy - bezwzględne przeszkody rejestracji, Warszawa 2009, p. 102

${ }^{37}$ M. Witkowska, A. Michalak, Znaki towarowe i oznaczenia geograficzne, [in:] Prawo własności przemystowej. Komentarz, ed. A. Michalak, Warszawa 2016, p. 353.

38 Judgement for the Sieckmann case, point 52.

39 Judgement of the CJEU of 27 October 2005, case T-305/04, Eden SARL v. OHIM, ECLI:EU:T:2005:380, points 24 and 25, hereinafter: judgement for the Eden SARL case. 
Another important example regarding the interpretation of the prerequisites registration for the unconventional visible trade mark was the cause of the Apple Inc. v. Deutsches Patent- und Markenam $t^{40}$, regarding registration of Apple flagship store interior design, that means registration of the design as three-dimensional trade mark. The CJEU concluded that the representation flagship store of Apple which "depicts the layout of a retail store by means of an integral collection of lines, curves and shapes, may constitute a trade mark provided that it is capable of distinguishing the products or services of one undertaking from those of other undertakings". What more the CJEU concluded that "the layout of a retail outlet depicted by such a sign may allow the products or the services for which registration is sought to be identified as originating from a particular undertaking". The real status of this case looked as follows: on 10 November 2010, Apple obtained from the United States Patent and Trademark Office the registration of a three-dimensional trade mark consisting of the representation, by a drawing in colour, of its flagship stores for services within the meaning of Class 35 of the International (Nice) Classification of Goods and Services for the Purposes of the Registration of Marks ${ }^{41}$. Later on, Apple presented a request for territorial extension of protection for this trade mark under the Madrid Agreement concerning the international registration of marks. On 24 January 2013, the DPMA refused the extension of trade mark protection to German territory on the ground that "the depiction of the space devoted to the sale of the undertaking's products was nothing other than the representation of an essential aspect of that undertaking's business", so Apple appealed to the Bundespatentgericht against the DPMA's ${ }^{42}$. As T. Sherliker accurately noted: "The Court of Justice of the European Union (CJEU) has introduced the concept of a new type of registered trade mark - the layout of a retail store - and set out initial parameters and exceptions for its acceptance" ${ }^{43}$. The CJEU admitted that the presentation in the form of a simple drawing without indicating the size or proportion of the development of the sales area of goods can be registered as a trade mark for services that rely on the provision of those goods, but do not form an integral part of their marketing. The Court stated also that such a trade mark may be registered if it allows the applicant's services to be distinguished from those of other companies and if there are no grounds for refusing registration. According to

40 Judgement of the CJEU of 10 July 2014, case C-421/13, Apple Inc. v. Deutsches Patent- und Markenamt, ECLI:EU:C:2014:2070, hereinafter: judgement fot the Apple Inc. case.

${ }^{41}$ The International (Nice) Classification of Goods and Services for the Purposes of the Registration of Marks established by an Agreement concluded at the Nice Diplomatic Conference, on June 15, 1957, was revised at Stockholm, in 1967, and Geneva, in 1977, and amended in 1979, hereinafter: the Nice Classification.

42 Judgement for the Apple Inc. case, points 8, 10, 11, 12, 19, 20.

${ }^{43}$ T. Sherliker, The registered layout: A new type of trade mark for Apple, "Journal of Intellectual Property Law and Practice” 2014, vol. 9(12), DOI: https://doi.org/10.1093/jiplp/jpu169, p. 961-963. 
the Court, a sign which represents the development of the manufacturer's flagship stores may be registered for goods as well as services, if these services are not an integral part of the marketing of the goods in question ${ }^{44}$. Due to the information of the Common Communication on the representation of new types of trade marks and the Common Communication regarding the distinctiveness of three-dimensional marks (shape marks), containing verbal and/or figurative elements, when the shape is not distinctive by itself it appears that nowadays the shape marks should be presented by providing a graphic reproduction of the shape, also a computer-generated image, as well as photographic reproduction, which may contain different shots. If a non-distinctive shape contains an element that is distinctive on its own, it will suffice to render the sign as a whole distinctive. The proportion and size of the verbal/figurative elements, their actual position on the shape, their contrast with respect to it are all elements which may affect the perception of the sign when assessing its distinctiveness ${ }^{45}$. For submissions made in electronic form, all shots must be submitted in one JPEG file ${ }^{46}$.

Significantly, according to the sentence of 24 June 2004 case Heidelberger Bauchemie $\mathrm{GmbH}^{47}$, the CJEU stated that colours or combinations of colours claimed in abstractive mode without contours, and the shades were indicated by reference to a colour sample and specified according to an internationally recognized colour classification system may constitute a trade mark where it has been established that, in the context in which they are used, "those colours or combinations of colours in fact represent a sign, and the application for registration includes a systematic arrangement associating the colours concerned in a predetermined and uniform way", colours or combinations of colours are "capable of conveying precise information" about the origin of goods and services.

According to the CJEU judgement of 6 May 2003, case Libertel Groep BV v. Benelux-Merkenburea $u^{48}$ it is considered insufficient to reproduce on paper the colour in question, but may be satisfactory by "designating that colour using an inter-

${ }^{44}$ Judgement for the Apple Inc. case, points 26 and 27.

${ }^{45}$ Common Communication on the representation of new types of trade marks, https://euipo. europa.eu/tunnel-web/secure/webdav/guest/document_library/contentPdfs/about_euipo/who_we_are/ common_communication/common_communication_8/common_communication8_en.pdf [access: 20.04.2020], p. 3; Common Communication: Distinctiveness of three-dimensional marks (shape marks) containing verbal and/or figurative elements when the shape is not distinctive in itself, https:// euipo.europa.eu/tunnel-web/secure/webdav/guest/document_library/News/cp9/CP9_en.pdf [access: 20.04.2020].

${ }^{46}$ E. Demby-Siwek, Nowe rodzaje znaków towarowych w polskim Prawie własności przemystowej, „Kwartalnik Urzędu Patentowego RP” 2019, no. 1, p. 109.

47 Judgement of the CJEU of 24 June 2004, case C-49/02, Heidelberger Bauchemie, ECLI:EU:C:2004:38.

48 Judgement of the CJEU of 6 May 2003, case C-104/01, Libertel Groep BV v. Benelux-Merkenbureau, ECLI:EU:C:2003:244, point 68. 
nationally recognized identification code". One should point, that deliberated colour layer of the mark may significantly distinguish the product within trade ${ }^{49}$. Popular brands consequently and deliberately want to be associated with certain colour ${ }^{50}$. Colour per se in case of a trade mark is unshaped, with unspecified contours and independent from a form of its placement on the product ${ }^{51}$. Describing the colour one should use an identification code in one of the following systems: PANTONE, RAL, CMYK, considered as accurate and durable ${ }^{52}$. Currently, colour as a trade mark should be presented by providing a colour reproduction while indicating that colour by reference to a universally recognized colour code or reproduction, which in a unified and predetermined manner shows a systematic arrangement of colour combinations, together with an indication of these colours by reference to a generally recognized code colour. One can also attach a description that explains the systematic arrangement of these colours ${ }^{53}$.

The cases resolved within jurisdiction show that fulfilling the requirement of graphical representability in reference to trade marks other than visually perceived has been problematic ${ }^{54}$. As for the time being the regulations of the Industrial Property Law do not close the catalog of signs that may be registered as trade marks. It is important that the sign applied for has a distinctive character and that it can be presented in the trade mark register ${ }^{55}$.

It is worth paying attention to the attempt to register a moving mark, which is an unconventional visual trade mark, which is a sequence of photo that does not make up a smooth animated image. Thus, the role of the consumer is to combine individual elements into the whole and complement the missing fragments of the animated image ${ }^{56}$. One may use the motion mark showing clasping hands, used by the company Nokia ${ }^{57}$. In a motion mark, it is precisely the motion and the sequence of scenes which are the most important aspects which may be subject to protection. According to M. Ziółkowski, care must also be taken, since motion marks cannot appear in trade in clear form, but only as a combination of marks, e.g. sound and movement ${ }^{58}$.

${ }^{49}$ M. Ziółkowski, Kolor jako cenny znak towarowy, „Rzeczpospolita” 26.06.2012, https:// archiwum.rp.pl/artykul/1153600-Kolor-jako-cenny-znak-towarowy.html [access: 5.12.2019].

${ }_{50}$ M. Kicia, Kolor per se jako znak towarowy w świetle orzecznictwa europejskiego, ,Rzecznik Patentowy" 2004, no. 1-2, p. 99.

${ }^{51}$ E. Wojcieszko-Głuszko, op. cit., p. 31.

${ }_{52}$ M. Rutkowska-Sowa, op. cit., p. 454.

${ }_{53}$ Common Communication on the representation..., p. 4.

${ }_{54}$ M. Witkowska, A. Michalak, op. cit., pp. 352-353.

${ }_{55}$ Co to jest znak towarowy?, https://uprp.gov.pl/pl/przedmioty-ochrony/znaki-towarowe/znaki-towarowe-informacje-podstawowe/co-to-jest-znak-towarowy [access: 5.04.2020].

${ }^{56}$ E. Wojcieszko-Głuszko, op. cit., p. 37.

57 Application CTM no. 003429909.

${ }_{58}$ M. Ziółkowski, Motion trademarks as an element of brand promotion, www.iplawwatch. com/2016/10/motion-trademarks-as-an-element-of-brand-promotion [access: 5.12.2019]. 
There has been an interesting attempt to register the motion trade mark "lambo doors" 59 which consisted of sequence of movements, showing the characteristic opening of the doors used in Lamborghini brand cars. Anyhow, it was not granted registration as a community trade mark by the OHIM. The submission of the mark included a description of the way the doors open, together with four sketches showing a sequence of the motion of the doors. That mark has been not registered because of its lack of distinctiveness, and because it was functional. However, in the USA, where this type of trade mark presentation is treated more liberally the application was approved ${ }^{60}$. After the amendment to the regulations, motion marks should be presented by submitting a video file or by means of a series of consecutive still images that show movement or a change in layout. Still images, however, can be numbered or contain a description that explains their order. The electronic file format for motion trade marks is JPEG and MP $4^{61}$.

An example of registration of the unconventional invisible trade mark is the case Venootschap Onder Firma Senta Aromatic Marketing's Application ${ }^{62}$. The firm applied to register as an olfactory mark "the smell of fresh cut grass" for goods, namely, tennis balls in Class 28 of the Nice Classification (registration expired). The OHIM stated, that the requirement of the graphic representability has been fulfilled. "The smell of freshly cut grass is a distinct smell which everyone immediately recognizes from experience. For many, the scent or fragrance of freshly cut grass reminds them of spring, or summer, manicured lawns or playing fields, or other such pleasant experiences". Also "the description provided for the olfactory mark sought to be registered for tennis balls is appropriate and complies with the graphical representation requirement of Article 4 CTMR". The decision of the OHIM positively referring to registration of the fresh cut grass smell as a trade mark should be treated as an exception. One should take into consideration that the later issued statements ${ }^{63}$ strengthen the opposite stand for the graphical representability of scent marks ${ }^{64}$.

It should be stressed that there is no protection to scent or taste marks, due to the fact that the current technology level doesn't permit to present those marks in a clear, precise, self-contained, easily accessible, intelligible, durable and objective

${ }^{59}$ Application CTM no. 001400092.

${ }^{60} \mathrm{M}$. Ziółkowski, Motion trademarks...

${ }^{61}$ Common Communication on the representation..., p. 4.

62 Venootschap Onder Firma Senta Aromatic Marketing's Application, 1999, E.T.M.R. 429 OHIM Bo A R156/1998/2.1999, https://euipo.europa.eu/eSearchCLW/\#basic/*///name/smell [access: 5.12.2019].

${ }^{63}$ Decision of the OHIM of 5 December 2001, R 711/1999-3.

${ }^{64}$ E. Wojcieszko-Głuszko, op. cit., p. 45. 
way $^{65}$. An interesting example of attempt to get a trade mark protection is the case regarding the registration of "Smell of ripe strawberries"

There is no taste mark registered as trade mark yet. Taking into consideration the necessity of graphical representability as included in the Sieckmann case the registration of taste signs should be adjudged as impermissible ${ }^{67}$. It seems possible in the future this situation will change and it may, thanks to technological progress, to register smell and taste trade marks. The amended provisions give the opportunity to register marks that can be reproduced in the register in a clear, precise, self-contained, easily accessible, intelligible, durable and objective way to enable competent authorities and the public to clearly and precisely define the subject of protection granted to the trade mark owner, which they will give to be presented in an appropriate form using widely available technology. The Polish Patent Office distinguishes, e.g. in the category of trade marks the "other" mark, i.e. if the trade mark applied for does not correspond to any of the categories stated by the office, it must be represented in an appropriate form using generally available technology. The mark must be capable of being reproduced in the register in a clear, precise, self-contained, easily accessible, intelligible, durable and objective manner ${ }^{68}$. The change in the definition of a trade mark and a kind of "liberalization" of registration prerequisites is a consequence of the jurisprudence of the Court of Justice of the European Union.

\section{CONCLUSION}

The issue of trade mark registration requirements has long aroused heated discussion within the area of literature of the subject. For obvious reasons, the jurisprudence for a long time focused on the requirement of graphic representation of the sign in the context of registration difficulties of marks "escaping" from their unambiguous description ${ }^{69}$. Strict treatment of registration obstacles was accompanied by, at the same time, progressive liberal practice, aimed at enabling registration of as many trade marks as possible in various forms of representation ${ }^{70}$.

${ }^{65}$ E. Demby-Siwek, Nowe rodzaje znaków..., p. 112.

${ }^{66}$ Judgement for the Eden SARL case.

67 J. Sitko, op. cit., p. 608.

${ }^{68}$ Common Communication on the representation..., p. 4.

69 A. Michalak, Interes publiczny i jego oddziaływanie na powstanie, treść i wykonywanie praw własności intelektualnej, Warszawa 2012, p. 123 ff.; J. Mordwiłko-Osajda, op. cit., p. 122 ff.; P. Funka, Zdolność odróżniająca znaku towarowego w aspekcie prawnoporównawczym, „Zeszyty Naukowe Uniwersytetu Jagiellońskiego. Prace z Prawa Własności Intelektualnej” 2006, no. 95, p. 26.

70 J. Mordwiłko-Osajda, op. cit., p. 122; M. Lampart, Uwagi do proponowanych zmian w przepisach unijnych w zakresie ochrony znaków towarowych, „Kwartalnik Krajowej Szkoły Sądownictwa i Prokuratury" 2014, no. 4(15), p. 31. 
Ultimately, these trends were reflected in secondary European Union law. What refers to the Polish law, it should be noted that the implementing provisions have not been adapted to the new act. The Polish Patent Office issued guidelines in the form of Common Communications, which are not legally binding, but their use is postulated by the office in order to standardize the practice of presenting signs and examining trade mark applications ${ }^{71}$.

The change of definition of trade mark should be positively judged due to the increasing number of unconventional signs registered as trade marks. One could even risk statement, that normative solutions have been "adapted" to trading practice. Deletion of prerequisite of graphical representability of the sign may help with easier obtaining the trade mark protection for the marks which graphical representation was difficult due to perception of the sign with other senses than vision. This way the number of registrations of unconventional trade marks should increase $^{72}$ and the trade mark protection would become more effective ${ }^{73}$. One has to agree with P. Kostański and T. Marek, that resignation of the requirement of graphical representability of the sign may be concerned as the trade mark law modernization ${ }^{74}$. Specific registration requirements for unconventional trade marks are indicated in Article 3 of the Regulation 2018/626. At the same time, it seems that their interpretation will be made systematically by the Luxembourg tribunal when examining cases in the field of registration of unconventional marks. Independently to the cancellation of the requirement of graphic representability, it can be pointed out that the main criterion to which the Court of Justice refers when dealing with unconventional trade mark cases remains the distinctive ability of the sign.

\section{REFERENCES}

\section{Literature}

Andrzejewski M., Znaki towarowe i oznaczenia geograficzne, [in:] Prawo własności przemystowej. Komentarz, ed. P. Kostański, Warszawa 2014.

Co to jest znak towarowy?, https://uprp.gov.pl/pl/przedmioty-ochrony/znaki-towarowe/znaki-towarowe-informacje-podstawowe/co-to-jest-znak-towarowy [access: 5.04.2020].

${ }^{71}$ The Common Communications have been developed by the national intellectual property offices together with the European Intellectual Property Office (EUIPO) as part of the "Convergence Program”. See UPRP, Konwergencja, https://uprp.gov.pl/pl/konwergencja [access: 22.04.2020].

${ }_{72}$ M. Lampart, op. cit., p. 31.

73 Ibidem, p. 27.

${ }^{74}$ P. Kostański, T. Marek, Wybrane zagadnienia nowelizacji europejskiego prawa znaków towarowych, „Zeszyty Naukowe Uniwersytetu Jagiellońskiego. Prace z Prawa Własności Intelektualnej” 2015, no. 130, p. 449. 
Common Communication: Distinctiveness of three-dimensional marks (shape marks) containing verbal and/or figurative elements when the shape is not distinctive in itself, https://euipo.europa.eu/ tunnel-web/secure/webdav/guest/document_library/News/cp9/CP9_en.pdf [access: 20.04.2020].

Common Communication on the representation of new types of trade marks, https://euipo.europa. eu/tunnel-web/secure/webdav/guest/document_library/contentPdfs/about_euipo/who_we_are/ common_communication/common_communication_8/common_communication8_en.pdf [access: 20.04.2020].

Definicja znaku towarowego, https://euipo.europa.eu/ohimportal/p1/trade-mark-definition [access: 5.04.2020].

Demby-Siwek E., Nowe rodzaje znaków towarowych w polskim Prawie własności przemystowej, „Kwartalnik Urzędu Patentowego RP” 2019, no. 1.

Demby-Siwek E., Zmiana systemu rozpatrywania zgłoszeń znaków towarowych, „Kwartalnik Urzędu Patentowego RP” 2015, no. 4.

Funka P., Zdolność odróżniająca znaku towarowego w aspekcie prawnoporównawczym, „Zeszyty Naukowe Uniwersytetu Jagiellońskiego. Prace z Prawa Własności Intelektualnej”2006, no. 95.

Kicia M., Kolor per se jako znak towarowy w świetle orzecznictwa europejskiego, „Rzecznik Patentowy" 2004, no. 1-2.

Koczanowski J., Funkcje i ochrona prawna znaków towarowych, „Zeszyty Naukowe Uniwersytetu Jagiellońskiego. Prace z Wynalazczości i Ochrony Własności Intelektualnej” 1976, no. 8.

Kostański P., Marek T., Wybrane zagadnienia nowelizacji europejskiego prawa znaków towarowych, „Zeszyty Naukowe Uniwersytetu Jagiellońskiego. Prace z Prawa Własności Intelektualnej” 2015, no. 130.

Lampart M., Uwagi do proponowanych zmian $w$ przepisach unijnych $w$ zakresie ochrony znaków towarowych, „Kwartalnik Krajowej Szkoły Sądownictwa i Prokuratury” 2014, no. 4(15).

Michalak A., Interes publiczny i jego oddziatywanie na powstanie, treść $i$ wykonywanie praw własności intelektualnej, Warszawa 2012.

Mordwiłko-Osajda J., Znak towarowy - bezwzględne przeszkody rejestracji, Warszawa 2009.

Prezydent podpisat nowelizację Prawa własności przemysłowej, 2019, www.gov.pl/web/rozwoj/ prezydent-podpisal-nowelizacje-prawa-wlasnosci-przemyslowej [access: 5.04.2020].

Promińska U., Znaki towarowe i prawo ochronne, [in:] Własność przemysłowa i jej ochrona, eds. E. Nowińska, U. Promińska, K. Szczepanowska-Kozłowska, Warszawa 2014.

Przedstawienie graficzne - rodzaje znaków, https://euipo.europa.eu/ohimportal/pl/elimination-ofgraphical-representation-requirement [access: 5.12.2019].

Rutkowska-Sowa M., Prawo znaków towarowych, [in:] Prawo własności intelektualnej, ed. J. Sieńczyło-Chlabicz, Warszawa 2018.

Sherliker T., The registered layout: A new type of trade mark for Apple, "Journal of Intellectual Property Law and Practice" 2014, vol. 9(12), DOI: https://doi.org/10.1093/jiplp/jpu169.

Sitko J., Znaki towarowe i prawa ochronne, [in:] Prawo własności przemysłowej. Komentarz, eds. T. Demendecki, A. Niewęgłowski, J. Sitko, J. Szczotka, G. Tylec, Warszawa 2015.

Szewc A., Mazurek M., Postępowanie w sprawie udzielenia prawa ochronnego na znak towarowy, [in:] System Prawa Prywatnego, vol. 14b: Prawo własności przemysłowej, ed. R. Skubisz, Warszawa 2012.

Venootschap Onder Firma Senta Aromatic Marketing's Application, 1999, E.T.M.R. 429 OHIM Bo A R156/1998/2.1999, https://euipo.europa.eu/eSearchCLW/\#basic/*///name/smell [access: 5.12.2019].

Witkowska M., Michalak A., Znaki towarowe i oznaczenia geograficzne, [in:] Prawo własności przemystowej. Komentarz, ed. A. Michalak, Warszawa 2016. 
Wojcieszko-Głuszko E., Pojęcie znaku towarowego. Rodzaje oznaczeń. Kategorie znaków towarowych, [in:] System Prawa Prywatnego, vol. 14b: Prawo własności przemystowej, ed. R. Skubisz, Legalis 2017.

Ziółkowski M., Kolor jako cenny znak towarowy, „Rzeczpospolita” 26.06.2012, https://archiwum. rp.pl/artykul/1153600-Kolor-jako-cenny-znak-towarowy.html [access: 5.12.2019].

Ziółkowski M., Motion trademarks as an element of brand promotion, www.iplawwatch.com/2016/10/ motion-trademarks-as-an-element-of-brand-promotion [access: 5.12.2019].

Ziółkowski M., Rodzaje znaków towarowych ze względu na ich percepcję zmysłami oraz przedstawialność w rejestrze, „Przegląd Prawa Handlowego” 2015, no. 1.

Ziółkowski M., Zmiany w zakresie wymogu przedstawialności znaku towarowego $w$ dyrektywie 2015/2436/12, „Przegląd Prawa Handlowego” 2016, no. 12.

\section{Legal acts}

Act of 20 June 2000 - Industrial Property Law (Journal of Laws 2017, item 776).

Act of 20 February 2019 amending the Industrial Property Law (Journal of Laws 2019, item 501).

Commission Implementing Regulation (EU) 2018/626 of 5 March 2018 laying down detailed rules for implementing certain provisions of Regulation (EU) 2017/1001 of the European Parliament and of the Council on the European Union trade mark, and repealing Implementing Regulation (EU) 2017/1431 (OJ EU L 104/37, 24.04.2018).

Directive (EU) 2015/2436 of the European Parliament and of the Council of 16 December 2015 to approximate the laws of the Member States relating to trade marks (recast) (OJ EU L 336/1, 23.12.2015).

The International (Nice) Classification of Goods and Services for the Purposes of the Registration of Marks established by an Agreement concluded at the Nice Diplomatic Conference, on June 15, 1957, was revised at Stockholm, in 1967, and Geneva, in 1977, and amended in 1979.

Regulation 2017/1001 of the European Parliament and of the Council of 14 June 2017 on the European Union trade mark (OJ EU L 154/1, 16.06.2017).

Regulation of the Prime Minister of 8 December 2016 regarding filling and processing trade mark application (Journal of Laws 2016, item 2053).

\section{Case law}

Judgement of the CJEU of 12 December 2002, case C-273/00, Ralf Sieckmann v. Deutsches Patentund Markenamt, ECLI:EU:C:2002:748.

Judgement of the CJEU of 6 May 2003, case C-104/01, Libertel Groep BV v. Benelux-Merkenbureau, ECLI:EU:C:2003:244.

Judgement of the CJEU of 24 June 2004, case C-49/02, Heidelberger Bauchemie, ECLI:EU:C:2004:38. Judgement of the CJEU of 27 October 2005, case T-305/04, Eden SARL v. OHIM, ECLI:EU:T:2005:380. Judgement of the CJEU of 10 July 2014, case C-421/13, Apple Inc. v. Deutsches Patent- und Markenamt, ECLI:EU:C:2014:2070.

Judgement of the Supreme Administrative Court of 9 December 2011, GSK 1346/10, LEX no. 1134648 
Pobrane z czasopisma Studia Iuridica Lublinensia http://studiaiuridica.umes.pl Data: 26/04/2023 17:10:12

Admissibility of Unconventional Trade Marks Registration within the European Court...

\section{STRESZCZENIE}

W dniu 16 marca 2019 r. weszła w życie nowelizacja ustawy Prawo własności przemysłowej, która implementowała dyrektywę Parlamentu Europejskiego i Rady (UE) 2015/2436 z dnia 16 grudnia 2015 r. mającą na celu zbliżenie ustawodawstw państw członkowskich odnoszących się do znaków towarowych. Istotną zmianą, jaką wprowadziła nowelizacja, jest zniesienie wymogu graficznej przedstawialności znaku towarowego. Umożliwi to łatwiejszą rejestrację niekonwencjonalnych znaków towarowych. Celem niniejszego artykułu jest zaprezentowanie, jak w świetle orzecznictwa trybunału luksemburskiego przedstawiała się rejestracja niekonwencjonalnych znaków towarowych.

Słowa kluczowe: znak towarowy; niekonwencjonalny znak towarowy; graficzna przedstawialność; rejestracja znaku towarowego 